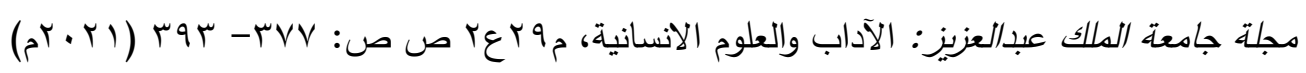

DOI:10.4197/Art.29-2.15

\title{
ملامح التفكير النحوي في وصف (مسألة الكحل) وتأويلها بين الحاجة والترف الفكري
}

\author{
د. فوزية بنت بداح بن مخلد العتيبي

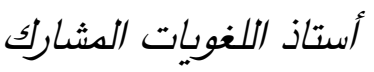 \\ قسم المواد العامة بكلية الآداب والعلوم الإنسانية \\ جدة- جامعة الملك عبد العزيز
}

falotaiebe@kau.edu.sa

مستخلص. مسألة الكحل هي إحدى النماذج التي اعترضت تطبيق نظرية العامل في الدرس النحوي؛ لخروجها عن

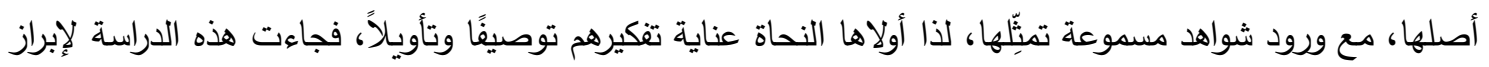

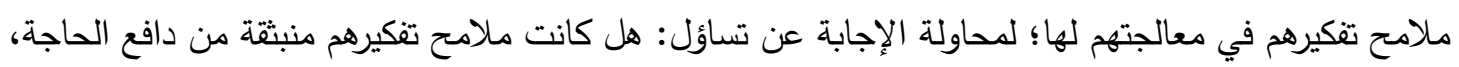

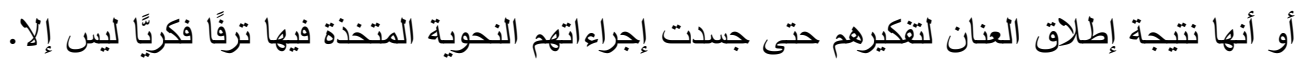

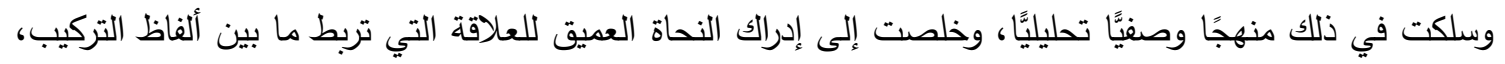

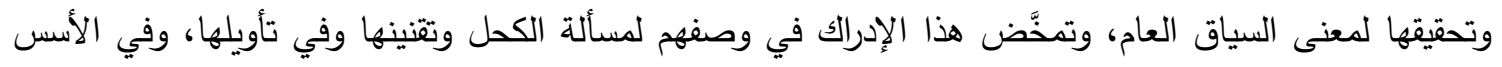

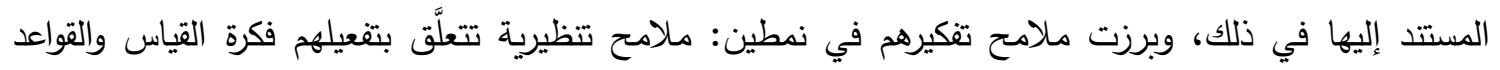

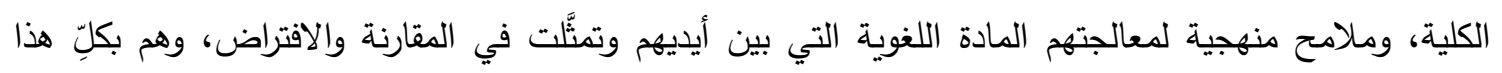

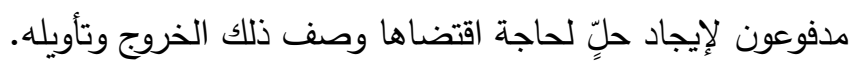
الكلمات المفتاحية: مسألة الكحل - اسم التفضيل-الحاجة- الترف الفكري.

\section{المقدمة}

تفكيرهم، لاسيما إذا كانت تلك المواد خارجة عن

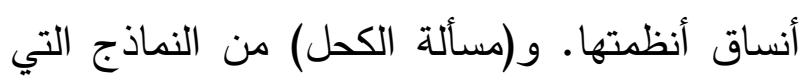
تجبِّد ما خرج عنه أصله، لذا فقد تعامل معها النحاة
الناظر في المصنفات النحوية لا يخفى عليه عناية

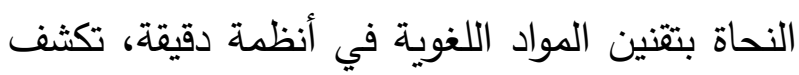
عن عمق فكرهم النحوي، المتجس في ملامح 
وإفراد التآليف الخاصة بها، ويذكر من ذلك على

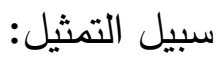

- (الوضع الباهر في رفع أفعل الظاهر لابن الصائخ) الذي نقله السيوطي في الأثباه والنظائر . - (رسالة على مسألة الكحل من الكافية) لهحمد بن الهن

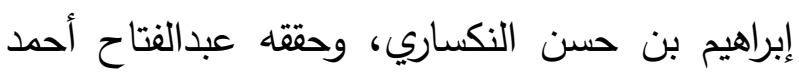

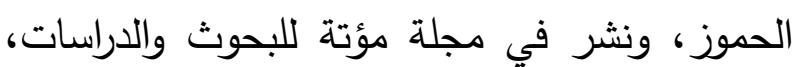

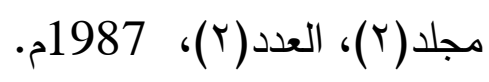

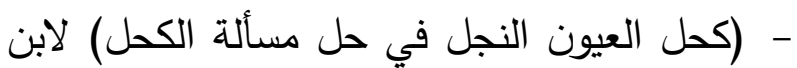
الحنبلي، وحققه حاتم بن صالح الضامن، ونشر في مجلة (المورد)، مجلد (rr)، العدد (l)، 1995م. وتكاد تتفق جميعها في تأصيل المسألة وبيان ما ورد فيها من آراء.

وافترقت عنها هذه الدراسة في تتبع ملامح التفكير النحوي في وصف النحاة لها وفي تأويلها، وإبرازها،

والأسس المستند إليها فيها، ومحاولة تقييمها. وسلكت في ذلك منهجًا وصفيَّا تحليليَّا، وانتظم بناؤها على محورين، يسبقهما توطئة؛ فالتوطئة (التأويل

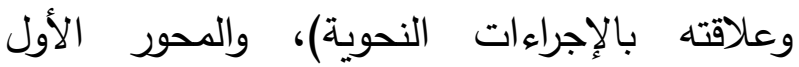

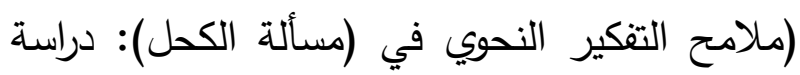
تحليلية)، والمحور الثاني (ملامح التفكير النحوي في وصف مسألة الكحل وتأويلها في الميزان). توطئة: التأويل وعلاقته بالإجراءات النحوية. يعود أصل كلمة (تأويل) إلى الرجوع إلى الثيء

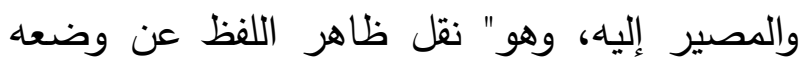

تعاملاً خاصَّا في مراحل متعددة من تطور الدرس

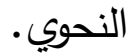
من هنا ظهرت فكرة الدراسة ومشكلتها؛ فهي تحاول الوقوف عند تنوَّع ملامح تفكيرهم النحوي في وصف المسألة وتأويلها؛ لتكثف عن منطلقات النحاة في معالجاتهم النحوية لها. التي تجسَّد تساؤل فرضيتها في التساؤل الآتي: ما

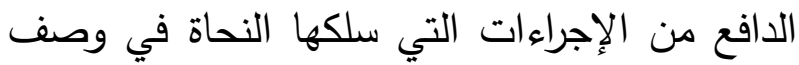
مسألة الكحل وتأويلها؟ وهل هي منبثقة من حاجة أو الو أنها من قبيل الترف الفكري؟ وتهدف من ذا إلى قراءة ملامح تفكيرهم النحوي في تعاملهم مع هذه السياقات وصفًا وتأويلاً؛ وفهمها؛ للتوصل إلى حقيقة دوافعهم من ذلك. وتكمن أهميتها في تقديمها خطوط عامة لتصور موضوعي عن الجهود التي بذلها النحاة من أجل تأصيل المواد اللغوية وتقنينها، وإبراز غايتهم من لنون ذلك، ومناقشة اعتراضات بعض الباحثين المحدثين على هذه الجهود، ودفع ما يمكن دفعه منها. وليس للدراسة مصطلحات خارجة عن المتعارف عليه في الدرس النحوي، ولا حدود مكانية أو زمانية لفكرتها؛ فكانت المصنفات النحوية عامَّة والمؤلفة في لوني مسألة الكحل خاصَّة منطلقاتها، التي استندت إليها إلى إبراز فكرتها؛ فالمطلع على الدرس النحوي يعلم

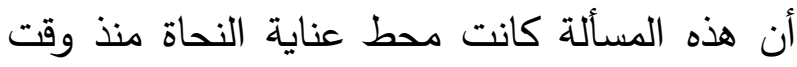
مبكر بل استمرت تشغل فكرهم حتى مراحله

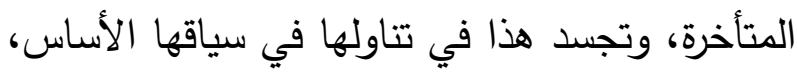


واستعمالهم التأويل -وإن كان المعنى ظاهرًا من دونه- قد يكون من قبيل التأكد من دقة أصولهي

واكتمالها. على أية حال، إنعام النظر في فكرة الأنموذج

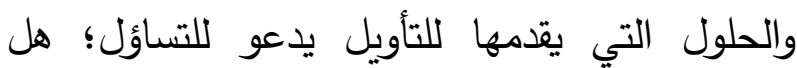

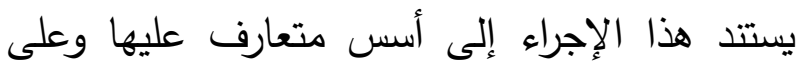
مواضعها أو أنه يخضع لاجتهادات النحاة ورؤاهم

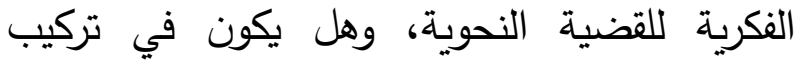
الجملة لفظًا ومعنَّى أو يقتصر على أحدهما؟ كما أن عملية التأويل التي من الففترض أن تكون الفيل

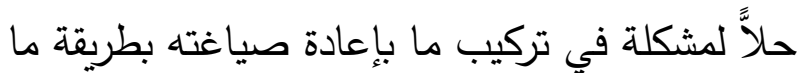

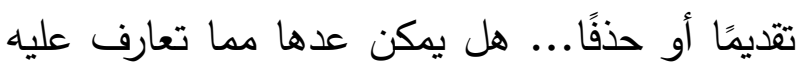
بلي عنق النص أو التركيب، وإخراجه عن واقعه؟ ولاسيها إذا كثرت الإجراءات التأويلية فيه، وهل

تعكس تأثر التنكير النحوي بالعلوم الأخرى؟ مما يمكن قوله إن إجراء التأويل إجراء مقنن؛ فقد

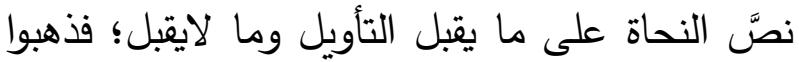
إلى أن مالا يتأول" هو اللغة التي لم يتكلًّ إلا بها، والثاذ. وعلى ذا، فاستعمالهم له مقنن بخروج التركيب عن

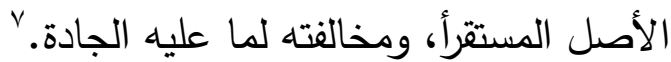

• بنظر : محمد عبد الفتاح الخطيب، ضو ابط الفكر النحوي، جـا (القاهرة:

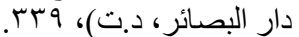

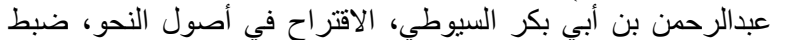
وتعليق: عبدالحكيم عطية، طبن (دمشق: دار البيروني،

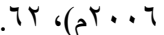
بيظر: أبو حيان الأندلسي، التذييل و التكميل في شرح كتاب التسهيل،

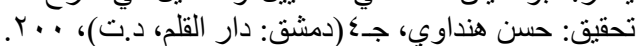

الأَصلي إلىى ما يَتَاج إلى دليلٍ لولاه ما ثُرك ظاهرُ اللفظ."' الاصلي والتأويل في العرف النحوي لم يبعد عن ذلك؛؛ إذ يراد به الإجراء اللغوي الذي يسلكه النحاة لإيجاد حلول

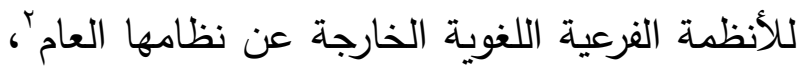
وقد تتعدد إجراء اته تبعًا لطرائق المعالجة، لكنها تتفق في فكرة وجود أنموذج تُرجع إليه تأويلاتها بشتى الجنى

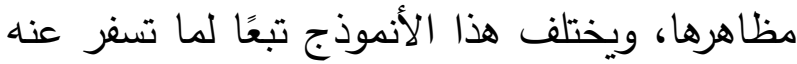
إجالة النحوي لنظره فيه. وهو مرتبط بنظام متخيل في ذهن المتأوِّل، الهدف منه إيجاد توازن بين القواعد وما خرج عنها؛ أي أنه نظام فرعي مكمل للنظام الأساسي.

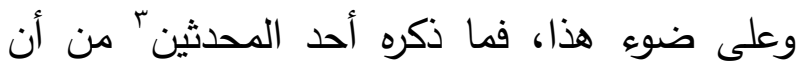
وجوده في الدرس النحوي كان حلاً لاستعجال النحاة الناة في وضع قواعدهم استنادًا إلى الاستقراء الناقص، الاقياك قبل إحصاء النصوص كلها وهو الذي جعلها عاجزة عن استيعاب ما خرج عنها، وكذلك تشددهم في الأخذ عمن ينطبق عليه شروط الاحتجاج...؛

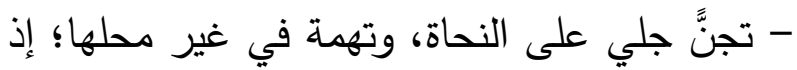
ما تقتينهم للاحتجاج إلا حرص على تقنين اللغة بعيدًا عن لوثة اللحن وما يؤدي إليه.

$$
\begin{aligned}
& \text { ' ابن منظور محمد بن مكرم، لسان العرب، جـ ' (بيروت: دار صادر، } \\
& \text { r محمد عبدالدايم، الاستدلال النحوي: نحو نظرية معاصرة لأصول النحو }
\end{aligned}
$$

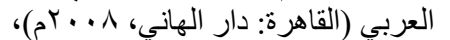

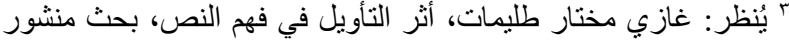

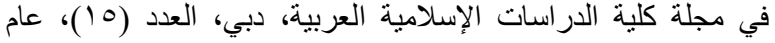

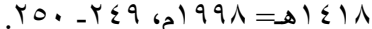

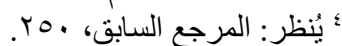




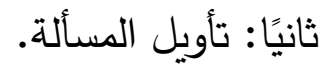
ثالثًا: الأسس المستتد إليها في وصف المسألة المسألة وتأويلها. أولاً: وصف المسألة وتقنينها. جاءت محاولة النحاة وصف مسألة الكحل أو تفسير عمل اسم التضضيل وتسويغه فيها مصطبغة بطابع عقلي تأصيلاً لحدِّها أو استدراكًا لتأصيل نحاة

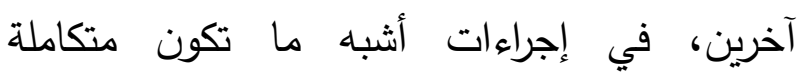
المقاصد؛ إذ تسعى إلى سدّ أي ثغرة قد تكون واردة.

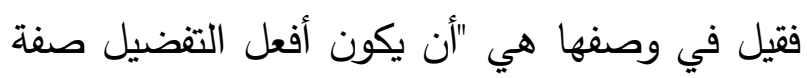
لشيء من حيث اللفظ، وهو في المعنى لمسبَّب ذلك الشيء، ويكون ذلك المسبب مفضَّلاً، أي ثابتًا له له زيادة الفضل باعتبار ما أجري عليه اسم التفضيل

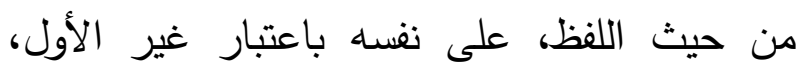
يعني: يكون المسبب مفضلاً ومفضلاً عليه باعتبار

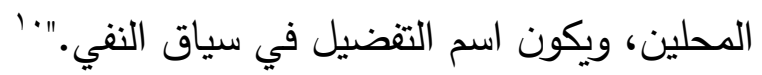

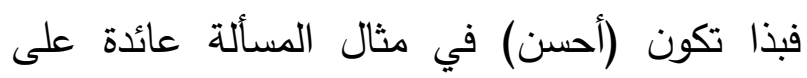

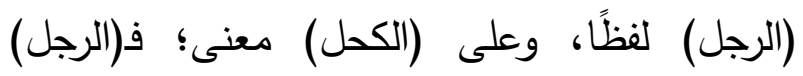

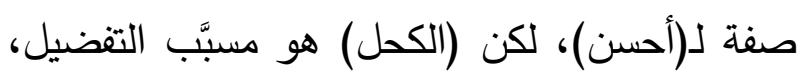

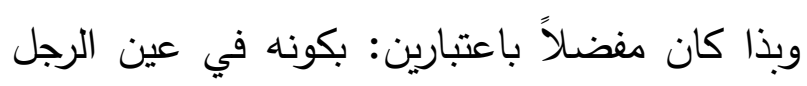

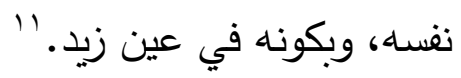
وإزاء هذا الفهر بدا أمر مشكل؛ فهل تعين زيله فيين ركني التفضيل في مثال المسألة في حالة مجيئه بصيغة

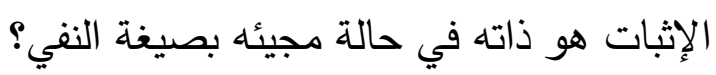

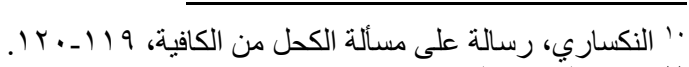

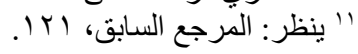

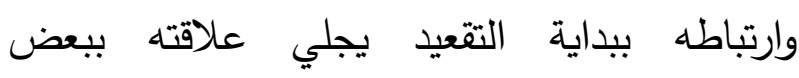
الإجراءات النحوية، كالتفسير، والتوجيه؛ فهي علاقة لباتية تكاملية؛ إذ يرد التأويل وجهًا من وجوه التفسير

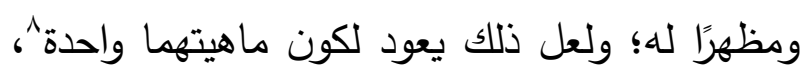
فيلجأ إليه النحوي لتحقيق مقصده من فهم التركيب، أو لحلِّ إثكال غموضه. كما أن اقترانه بالتوجيه لمحاولة فهم التركيب، يجلي حقيقة ارتباطهما ببعضهما البعض؛ إذ التوجيه التأويل بمظاهره -من تقديم وحذف...إلخ- جزء من التوجيه.

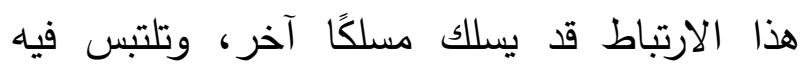
العلاقة بينهما وبين إبانة المعنى المحتمل، ويبعد التأويل عن تحقيق الأثر المراد؛ نتيجة للوهم في فهم

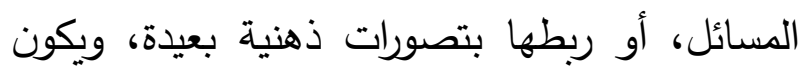
الاختلاف كبيرًا بين ما يحتمله المعنى ولا تقبله

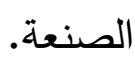

المحور الأول: ملامح التفكير النحوي في (مسألة (الكحل): دراسة تحليلية.

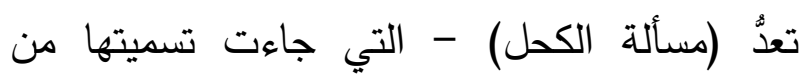

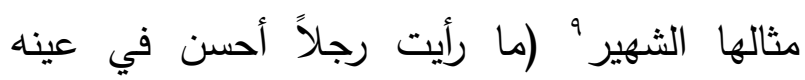
الكحل منه في عين زيد) -إحدى نماذج الخروج عن

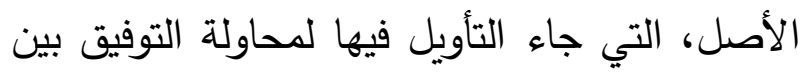
قواعد النحاة والتراكيب الخارجة عنها، وبرزت فيهاء ملامح التفكير النحوي، وتجسدت في الآتي: أولاً: وصف المسألة وتتنينها.

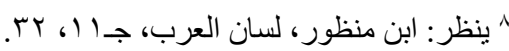

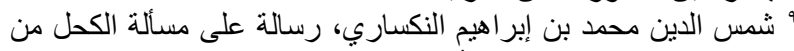

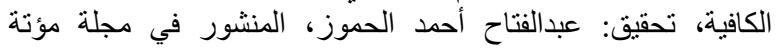

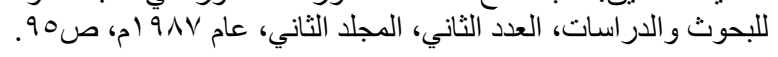


اسم التفضيل ورفعه الظاهر، وإشكال في فهم العلاقات التي تربط كلمات المثال ببعضها. بعبارة أخرى يمكن القول بأن المثال يمثل إثكالين: الإثكال الأول: يكمن في مخالفته القاعدة النحوية، لرئال ويمكن تجسيده في التساؤل: كيف رفع اسم التفضيل الاسم الظاهر وهو ضعيف الثبه بالفعل؟ والإشكال الثاني يكمن في معناه؛ ويمكن تجسيده في التساؤل: هل الحسن كائن للكحل أو للعين؟ تلمح ملامح التفكير النحوي في الإشكال الأول في سبر حقيقته؛ من ذلك ما ورد عن ابن مالك قوله: "ولا يرفع أفعل التفضيل في الأعرف ظاهرًا إلا قبل مفضول هو هو مذكور أو مقدر" الضمير المجرور الذي يعود إلى الاسم "الظاهر الذي فرض رفع أفعل التفضيل له وهو الكحل."يدا' كما تلمح في وعيهم بهذا الإشكال ومحاولة إيجاد مخرج للتخلص منه في استدراكاتهم وتعقيباتهم لإجراءات غيرهم؛ فمن ذلك قول ابن الصائغ: "ولا أعرف مخرجًا للغة من يرفع بها الظاهر مطلقًا كما سبق، لكن كان ينبغي أن يزيد أو ضميرًا منفصلاً

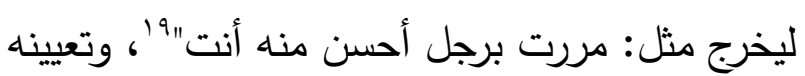

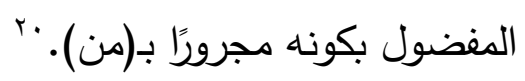

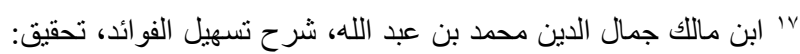

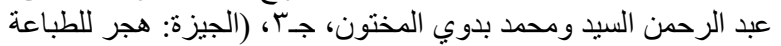

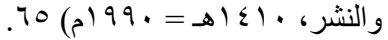

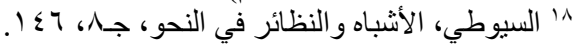

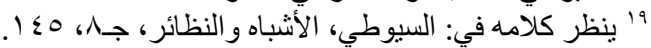

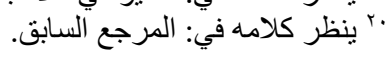

من تقليب النظر فيه يمكن الإجابة بالنفي؛ فهما حالتان متضادان؛ ففي حالة النفي يكون المفضل في اللفظ هو المفضل عليه في المعنى، والمفضل عليه في المعنى هو المفضل في اللفظ، 'أ- أي عكس ماهو عليه في صيغة الإثبات- وعلى ذا كيف يمكن التوفيق بين هذا وبين القول بأن (الكحل) هو مسبَّب

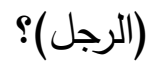
تتبثق الإجابة من أصل فهمهم لدلالة (المسبَّب)؛ فمنهم من استتد إلى دلالته اللغوية، فذهب إل أن

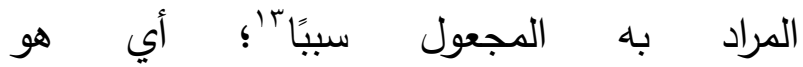
المتعلق، 'ف(الكحل) هو سبب الحسن في عين

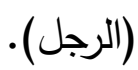
ومنهم من استند إلى دلالته العرفية فذهب إلى "أن التفضيل حقيقة للعين؛ فتكون "العين سببا للكحل في التفضيل، والكحل مسبَّب..101"

وعلى ذا فالنظر إلى المسألة يكون بحالة الإثبات إذ إذ إن النفي يوجب أن يكون ما بعد(من) أفضل مما قبلها؛ ف (أفعل) في سياق النفي المقصود به نفي الأفضلية والمساواة لما دخلت عليه (من) 7 (التيكي وبذا يمكن القول بأن بؤرة الإشكال في المسألة والمسيطرة على الفكر النحوي تتجسد في فرعين مكملين لبعضهما: إشكال في مخالفة الأصل لعمل

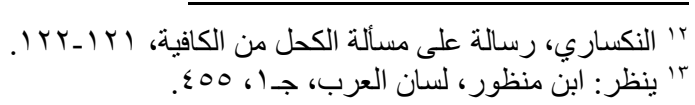

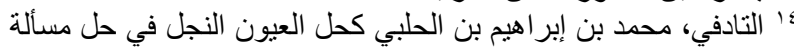

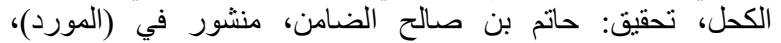

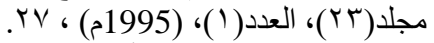

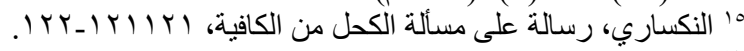
17 التادفي، محمد بن إبراني، اهيم بن الحلبي كحل العيون النجل في الني حل مسألة

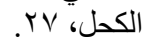


وتارة يقيسون رفعه الظاهر على رفعه الضمير؛ فهو يفضل المكان على غيره، ولا يمكن تفضيل الثيء على نفسه. وتارة يرون أن اتحاد المفضل والمفضل عليه في ذات واحدة - تفضيل الشيء على نفسه - جعل اسم

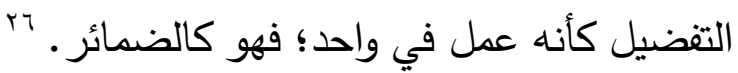
بل إن بعضهح خرج عن إطار فكرة القياسية ورأى أن

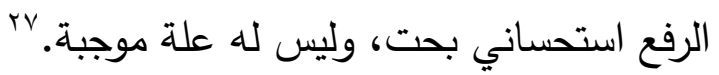
إنعام النظر في هذه التفسيرات يلمح منها تعدد الأسس المستند إليها في تقديم تفسيرات للمسألة وإن كان القياس الأصل المستند إليه كثيرًا في تفسير

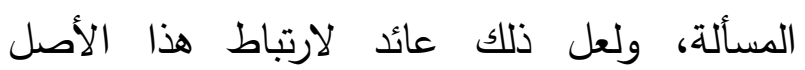
بالذهنية العربية، وكأنه أثبه باللازمة لها.

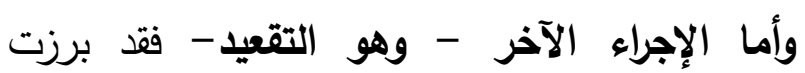

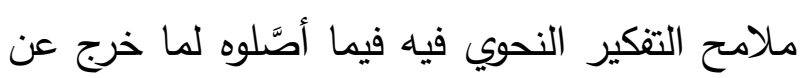
قواعدهم في هذا الشأن؛ إذ من المقرر في أصولهج

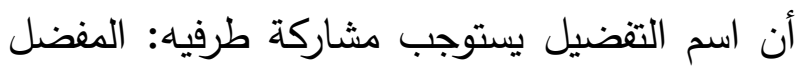
والمفضل عليه في الحدث، مع زيادة طرفه الأول

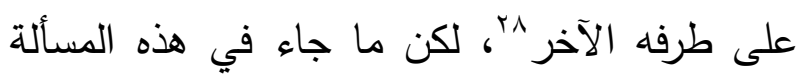

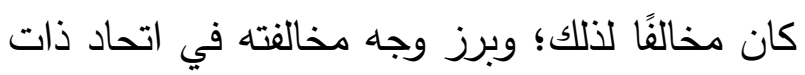
المفضل والمفضل عليه اتحادًا أدى إلى ضعف ونف ونى معنى التفضيل فيها وحكمه.

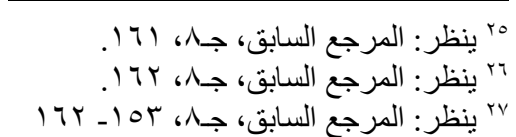

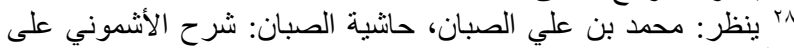

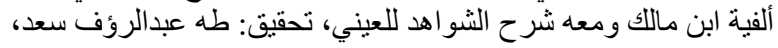

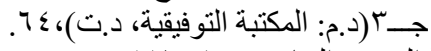

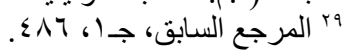

وفي محاولة تقريبه من ذلك الثبه بوضع اشتراطات

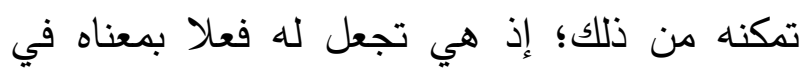

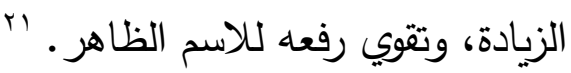

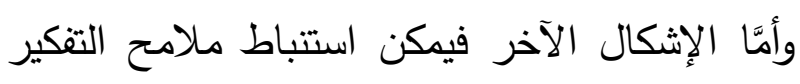

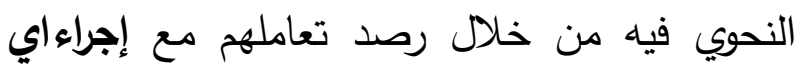
التفسير وإلتقعيد. فقد ظهرت ملامح التفكير النحوي في الإجراء الأول

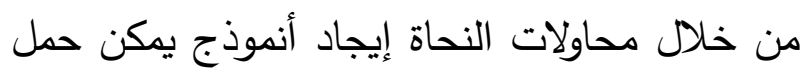
عمل اسم التقضيل عليه، وتعدد تفسيراتهم له، التي كانت في مجملها منبثقة من أسس قياسية متعددة؛

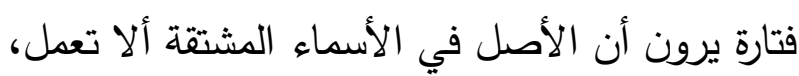

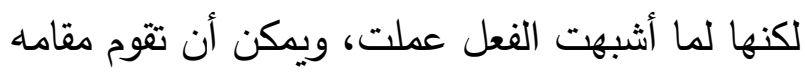
وأن تعاقبه، وتثيد ما يفيد. لكن قياسهم هذا جعلهم يصطدمون ببعد شبه اسم التفضيل عن الفعل؛ إذ ليس له فعل بمعناه الدال على الزيادة، وهذا تقسير عدم عمله.

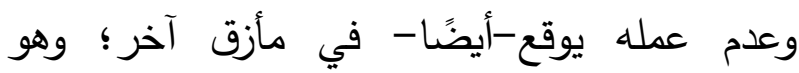

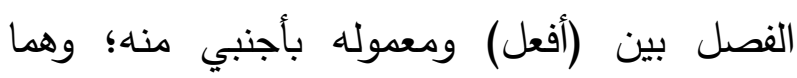
كالمتضايفين، اللذين لا يفصل بينهما بأجنبي أو لونهو

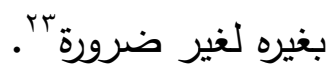
وعلى ذا، فهو إن لم يعمل ويرفع فاعلاً فسيكون

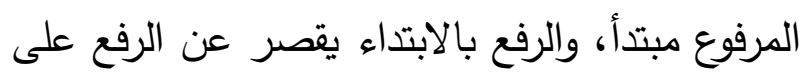

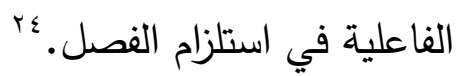

rrr التادفي، محمد بن إبر اهيم بن الحلبي كحل العيون النجل في حل مسألة

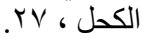

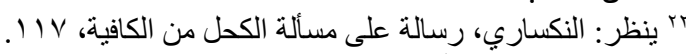

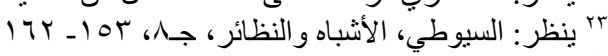

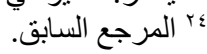


بعلاماته، وفي إدخال النفي إزالة لهذا الضعف،

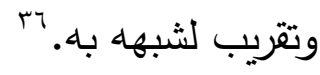

كما أن ضعف التفضيل الناجم عن اتحاد المفضل بهل والمفضل عليه ذانًا يمكن إزالته - أيضًا - بوجود أنساد النفي؛ فبوجوده لا يفهم من سياق المسألة أنه أريد مساواة الكحل في عين الرجل بالكحل في عين زيد؛

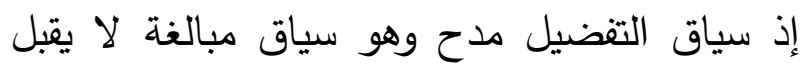

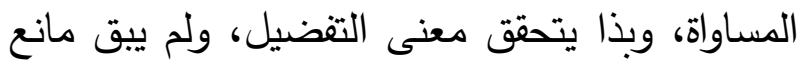
من عمله الرفع في الظاهر ؛ إذ يكون كالفعل، ويعمله لهابه مثله.

وتوصلوا إلى أن نفي المساواة حاصل في مثال المسألة باستعمال الفعل وباستعمال اسم التفضيل؛

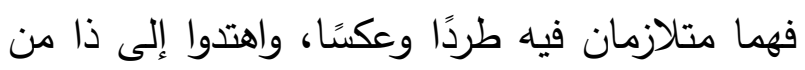
خلال استحضارهم لبعض القواعد الكلية، ب، منها: - التساوي بين الثيئين في الصدق آية كون كل

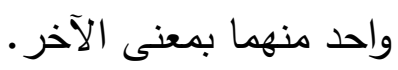
- تشبيه الثيء بالثيء يقتضي الا يكون المشبه زائًًا عن المشبه به.

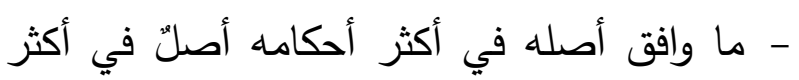
أحكامه أصل بالنسبة إلى ما خالفه فيه. وفي هذا تأصيل لملمح مرتبط بالفكر النحوي يتجسد في مراعاتهم ملابسات السياق وتظافرها لتحقيق المقصد؛ فالتعامل مع تركيب المسألة لم يكن بمعزل منافي

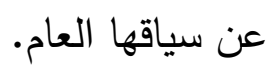

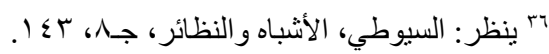

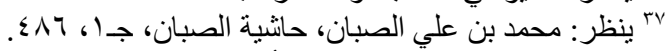

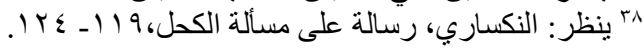

ولثبهه بـ (أفعل) التعجب وزنًا وأصلاً ودلالة على

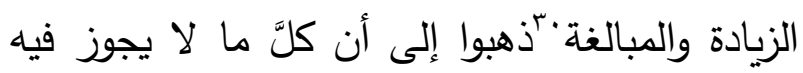

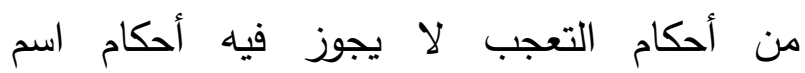
التضضيل 'ب، ولذا اختلف عن الصفة المشبهة بالتزامه لفظًا واحدًا عند تتكيره، وعدم رفعه الاسم الظاهر بَّ؛

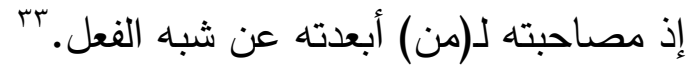

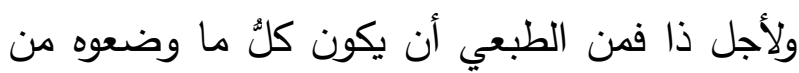
قيود في سياق إعادته إلى أصله حاملاً -بوجه أو أون آخر - بعدًا فكريا، يكثف عن أسس ملامح تفكيرهم

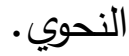

فاشتراطه ورود اسم التفضيل في سياق نفي \& لتسويخ عمله الرفع في الاسم الظاهر يُلْمَح منه ملمح لفيح

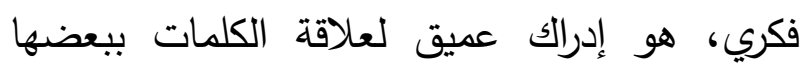

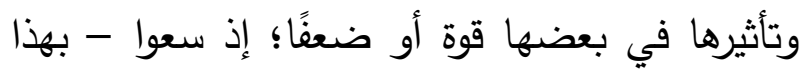

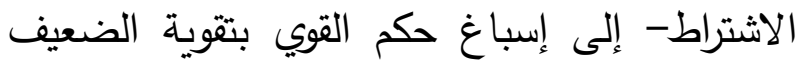
منها، الذي يهدف منه تحقيق تقويتين: تقوية شبه

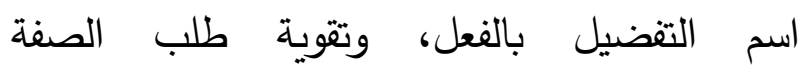
للموصوف. المبم والتقوية الأولى مستندة إلى أن ضعف التفضيل عائد لبعد شبهه بالفعل لعدم جريانه مجراه في لحاقه

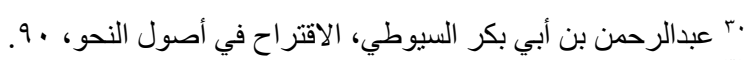

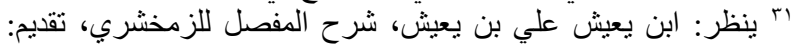

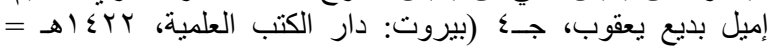

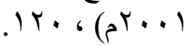
rr ينظر : أبو حبان الأندلسي، التذييل و التكميل في شرح كتاب التسهيل،

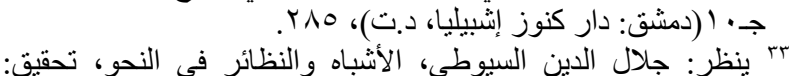

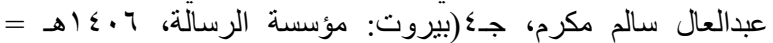

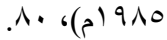
"s التادفي، محمد بن إبر اهيم بن الحلبي كحل العيون النجل في حل مسألة

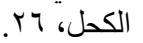
ro ro : النكساري، رسالة على مسألة الكحل، 1. 
النمط الأول: الفرار من تعارض الأصول.

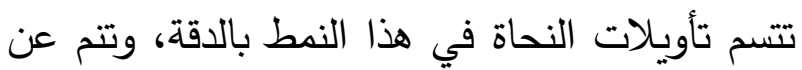
عقلية فطنة؛ إذ تساير بتسلسل عقلي التدرج في

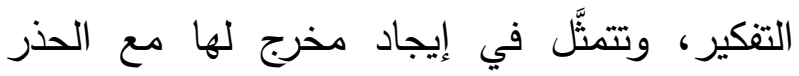
الثديد من الاصطدام بأصول نحوية. وانبثقت من تتبع الأثر الإعرابي للكلمات المشكلة

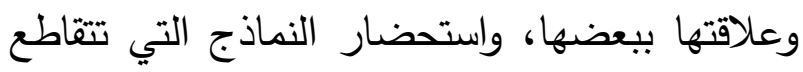
مع تركيبه، استتادًا إلى المخزون اللغوي وعقد

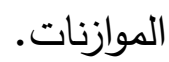

ويلحظ فيها استتادهم إلى أصول نظرية العامل؛ إذ إذ إنات توجيه الأثر الإعرابي لكلمتي (أحسن) و(الكحل) متوقف على هل اسم التفضيل في المسألة عامل أو الإن لاب، وعلى ضوء ذا فتوجيهما يتمنَّل في أحد أمرين: الأمر الأول: إن كان اسم التفضيل عاملاً فنصب داهب

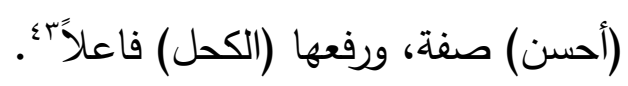

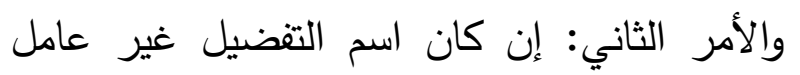

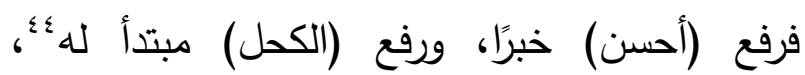
والعكس. إلا أن طريقة التقكير هذه قد تصطدم بأصول نحوية تابعة للاتجاه النحوي الذي ينتمي إليه النحوي ويعتد

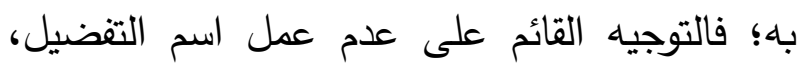
وكونه مع كلمة(الكحل) يمثلان ركني الجملة الاسمية

rاء أبو حيان، ارتثاف الضرب من لسان العرب، تحقيق وشرح ودر اسة:

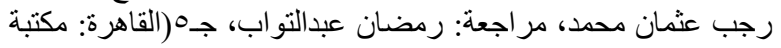

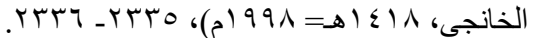
؛؛ الرضي الأسترباذي، شرح الرضي على على الكافية، تصحيح وتعليق:

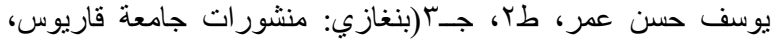

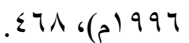

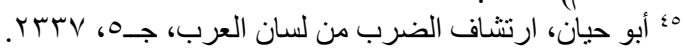

أما التقوية الأخرى فتستند إلى أن ضعف طلب الموصوف للصفة النكرة في سياق الإثبات أقل منه الهـ في سياق النفي؛ ففي الإثبات المقصد زيادة فائدة، وفي النفي تقرير الكلام ودرؤه عن الكذب.

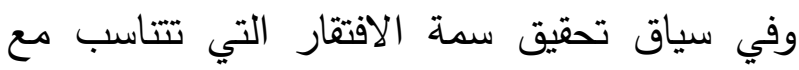
ملابسات هذا المقصد ومع سياق المسألة اشترطوا

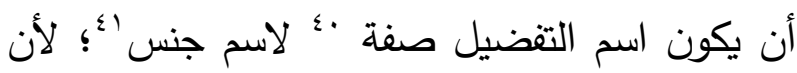

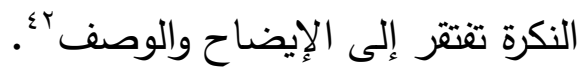
أما اشتراطهم أن يكون اسم التفضيل مفضلاً على الإنى ولى

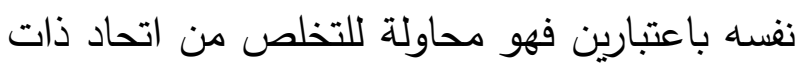
المفضل والمفضل عليه في مثال المسألة، وتحقيقًا لركني التفضيل. وبذا يمكن القول بأن هذه الاشتراطات تؤصل ملمحًا عامًا من ملامح التفكير النحوي وهو تحقيق التكامل في صوغ أسس القواعد النحوية الخارجة عن أصلها،

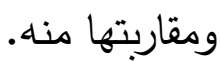

ثانيًا: ملامح التفكير النحوي في تأويل المسأكة. يمكن تصنيف ملامح التفكير النحوي في تأويل المسألة الكحل إلى نمطين: النمط الأول: الفرار من تعارض الأصول فئ. النمط الثاني: الاستناد إلى العصف الذئ نعارصن الاصني (تقليب

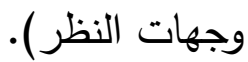

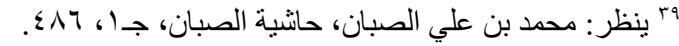

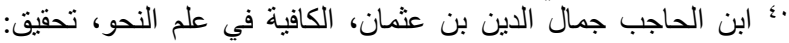

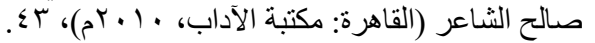

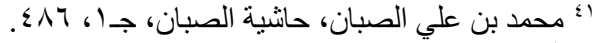
r أبو القاسم عبدالرحمن السهيلي، نتائج الفية الفكر في النحو (بيروت: دار

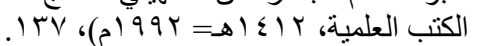


والمعموله؟ء- أي بين اسم التفضيل ور(من)-

$$
\text { ن. بأجنبي، وهو -هنا- المبتدأ. }
$$

وتتسم تأويلات هذا النمط بدقة الملاحظة والحرص على سد الثغرات، وعدم التكلف، والقرب من الواقع لهابع

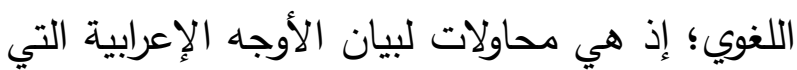
تحتملها الكلمتان المشكلتان في مثال المسألة، وتفسير علاقتهما ببعضهما ودلالة سياق المسألة، وهذه هي حاجتها ومقصدها، فهي بذلك إجراء طبيعي استدعته ملابسات السياق. النمط الثاني: الاستناد إلى العصف الذهني (تقليب وجهات (النظر). تمثل هذه الطريقة رافًا تكامليَّا للطريقة السابقة، وقد تتزامن معها ذهنيًّا؛ إذ هي أشبه ما تكون بعمليات حصر جميع الأوجه المحتملة؛ لمحاولة حلِّ إشكال المثال مع تجاوز إشكالات الاصطدام بالأصول

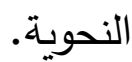

وقد ينجم عن هذه العمليات إعادة بناء تراكيب مثال

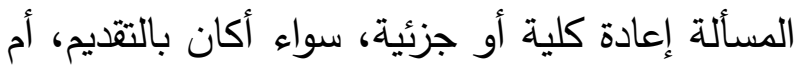
بالتأخير، أم بالحذف، ويمكن بيانها على النحو الآتي: بالتان

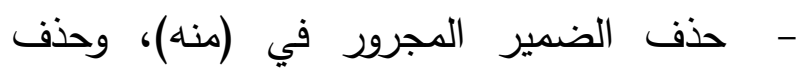
حرف الجر (في) من تركيب (في عين زيد) الذي هو

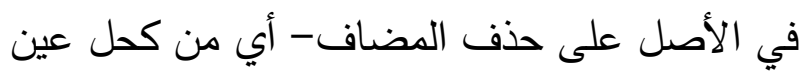
زيد- فيصبح تركيب المثال بعد الحذف: ما رأيت

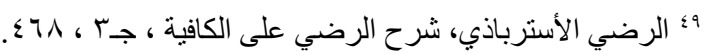

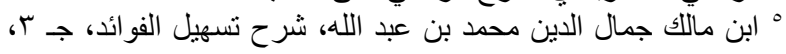

يصطدم عند البصريين بأصل إضمار الضمير الذي

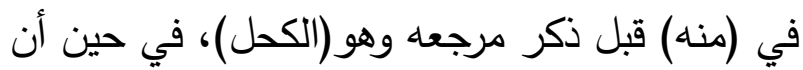
هذا الاصطدام لا يكاد يذكر عند الكوفيين، ولا يرونه

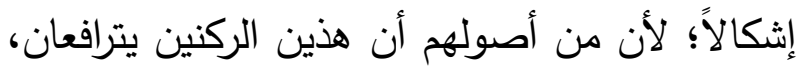

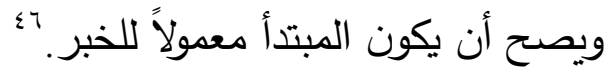
ومن هنا بدأت هذه الطريقة في التشعب الذهني فرارًا من تعارض التأويلات مع الأصول المستحضرة؛ فذهبوا إلى أنه لا يمكن أن يكون (الكحل) مبتدأ

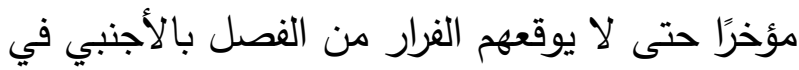

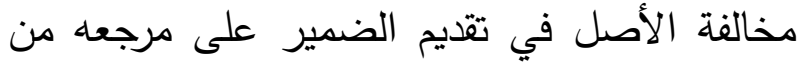
دون ضرورة، كما لا يمكن تقديمه على اسم التفضيل

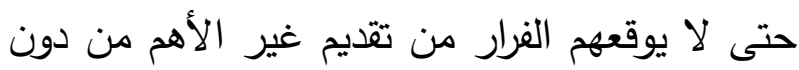

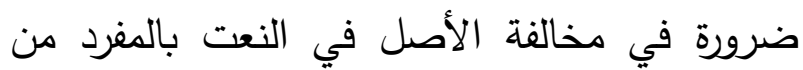
دون ضرورة أيضًا. لذا ذهب بعضهم إلى أن التأويل الذي قد يكون مناسبًا من دون الوقوع في كل هذه المحذورات هو

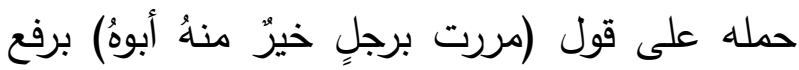

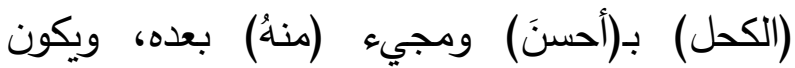
التقدير (ما رأيت رجلاً أحسنُ في عينه الكحلُ منه

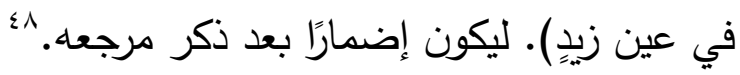
كما أن التوجيه القائم على كون الكلمة صفة رافعة لفاعلها اصطدم بأصل الفصل لوجل بين العامل

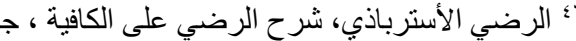

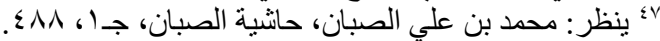

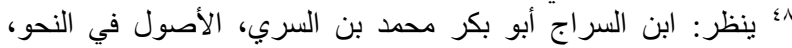

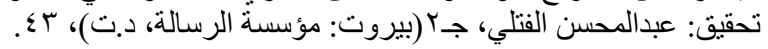


لكن ذلك لم يكن هو المقصد الذي أراده النحاة؛ إذ هم يحاولون بعملية عقلية إعادة التركيب إلى أصله أو ما يقاربه.

ثالثًا: ملامح التفكير النحوي في الأسس المستند إليها في وصف المسألة وتأويلها. من إنعام النظر فيما تَّ استعراضه يمكن تصنيف ملامح التنكير النحوي المستنبطة من الأسس المستتد إليها في وصف المسألة وتأويلها إلى نمطين: النمط الأول: ملامح تتظيرية تتعلق بالتأصيل والتقعيد، وتتمثل في القياس والقواعد الكلية. النمط الثاني: ملامح منهجية تطبيقية تتعلق بمعالجة ولئة المادة اللغوية، وتتمثل في المقارنة، والافتراض. وتأتي الملامح التتظيرية التي تتعلق بالتأصيل والتقعيد -وهي هنا القياس والقواعد الكلية- من لتصني الملامح الأولية التي تبرز الإجراءات التي سلكها

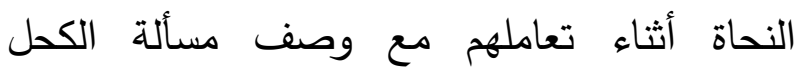
وتأويلها؛ إذ هي ترتكز -بوجه أو بآخر - على فكرة

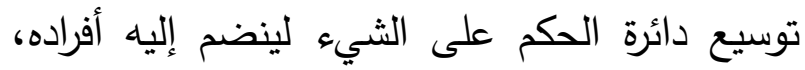

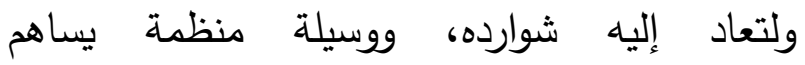
استحضارها في تعيين وجوه التقاطع بين التراكيب والتباعد بينها. وقد برز القياس في مسألة الكحل في منحيينهان: قياس تطبيقي تمثنّل في قياس مثال المسألة على في فئل نماذج سابقة متعددة مسموعة أو مصنوعة أو لئي

ro ينظر على سبيل التمثيل: إبراهيم بن موسى الثاطبي، المقاصد الثافية

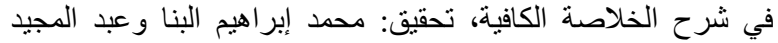

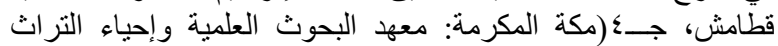

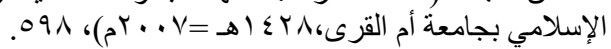

رجلاً أحسن في عينه الكحل من عين زيد.' - حذف الضمير المجرور في (منه)، وإدخال (من) ملهن

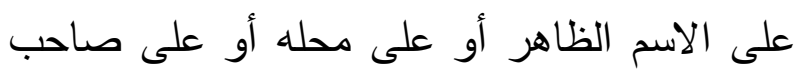

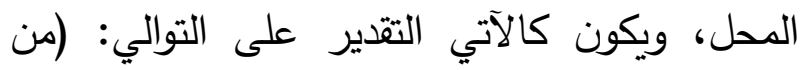
كحل زيد)، و(من عين زيد)، و (من زيد).

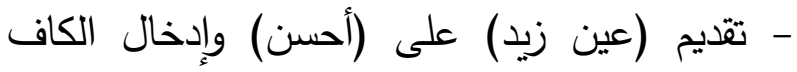

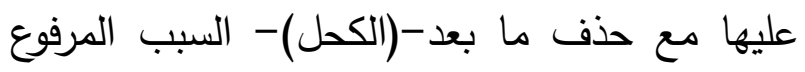
من المفضول وغيره، فيصبح تركيب المثال: ما رأيت

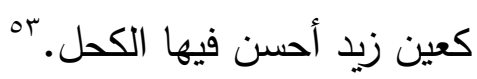
- تأخير المرفوع (الكحل)، ويكون التقدير: مررت برجل أحسن في عينه منه في عين زيد الكحل. ؛

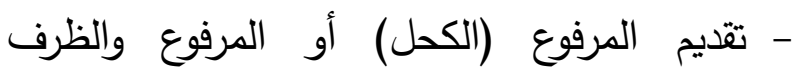
(الكحل في عينه) على اسم التضضيل، ويكون التقدير: ما رأيتُ رجلاً الكحل أحسن في عينه منه فئه

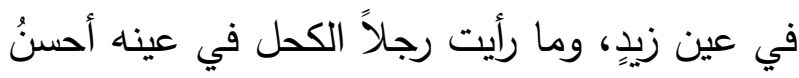
منأُ في عينِ زيدِ. ويمكن القول بأن تأويلات هذا الندط تتسم باستنادها

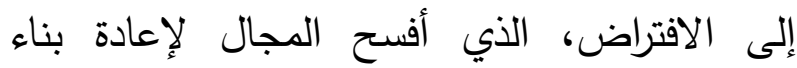
التركيب بتقديم بعض ألفاظه أو تأخيرها أو حذفها،

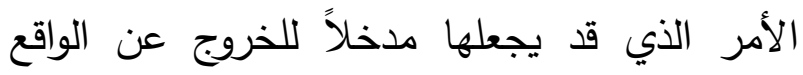
اللغوي بإعمال الفكر وافتراض ما قد يبعد عن من التركيب الأساس لمحاولة سدّ الثغرات المحتملة.

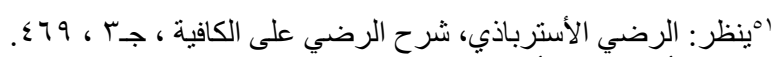
هويظزر: أبو حيان الأندلسي، التنييل والتكميل في شرح كتاب التسهيل،

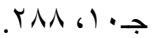

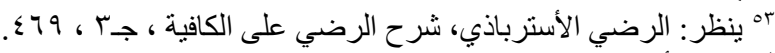

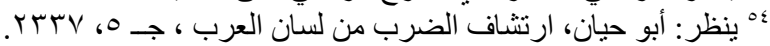

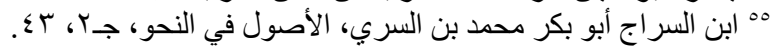


لسابقتها؛ فتأتي متزامنة معها، ومستقلة في أحايين أخرى؛ فتأتي منفصلة عنها. ولعل هذا أمر طبعي شأن أي أمر مرتبط بعالم أنس

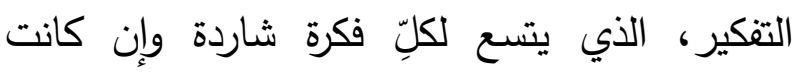

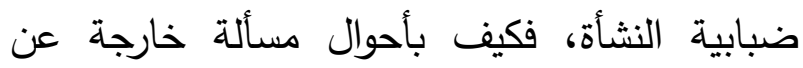

أصلها تلقتتها أذهان النحاة!

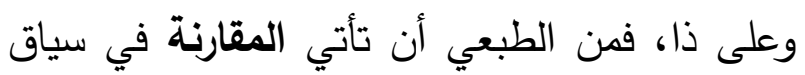

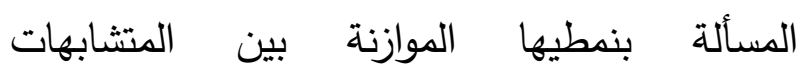
والمختلفات، ومن بعديها الشكلي والمعنوي. 9. فمن السياقات التي تتكثف فيها عنايتهم بالمقارنة

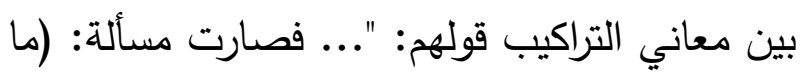

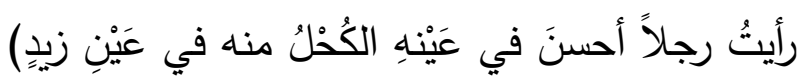
تُؤَدي من المعنى ما لا يؤدِّي غيرَّها من العبارات

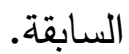

ولذلك لا يقال: إنه يمكن في الموضع عبارةٌ أخرى تؤدّي المعنى، وذلك أن/ تقول كـ (ما رأيتُ رجلاً الكحُل أحسنُ في عينه منه في عِين زيد)، ولا تحتاج

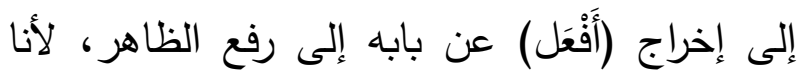

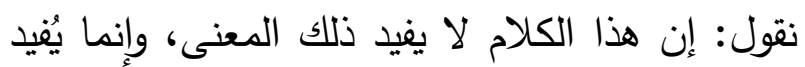
نفَي المزية، لا نفي المزية والمساواة معًا، فالضرورة مُلْجِيُة إليه." أمَّا الافتراض فقد ظهرت ملإمحه من خلال أشباه

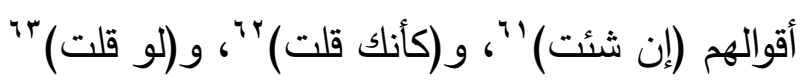

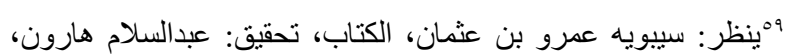

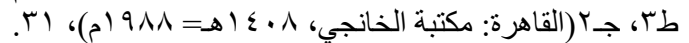

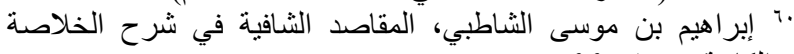
"ينظر على سبيل التمثيل: ينظر: سييويه عمرو بن عثمان، الكتاب،
العكس، وقياس نظري تمثَّل في قياس عمل اسم التفضيل على اسم الفاعل. وظهرت القواعد الكلية في المسألة في نسقها النحوي المألوف تارة، ومتداخلة مع النسق الفقهي عند بعض في فئل

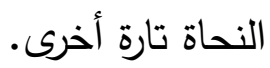
فمن توظيفها في نسقها -على سبيل التمثيل - فردا.

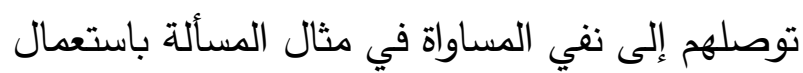
الفعل وباستعمال اسم التفضيل استتادًا إلى القاعدتين الكليتين vo كون كل واحد منهما بمعنى الآخر)، و (تشبيه الثيء بالثيء يقتضي ألا يكون المشبه زائدًا عن المشبه ونه بها. (ب)

ومن توظيفها متداخلة مع النسق الفقهي -على سبيل

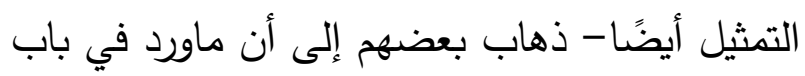

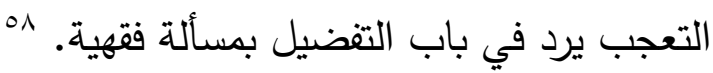

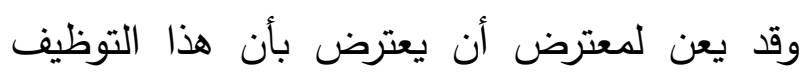

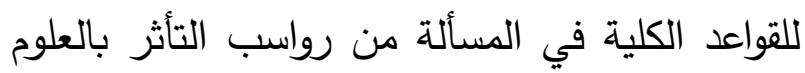

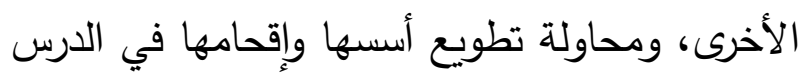
النحوي، والحق أن الأمر من الممكن أن يكون واردًا من باب كون هذه العلوم علومًا عقلية، تتحد فيها إجراءات التفكير بداهة، لكنه في المقابل لا يمكن القطع بأنها محاولات مقصودة لذلك الغرض. أما الملامح المنهجية التطبيقية التي تتعلق بمعالجة

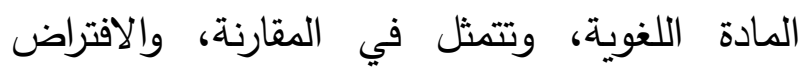
فيمكن عدُّها في بعض الأحايين ملامح مكملة

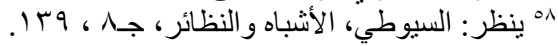


بمسلم إقادة ما يفيده اللفظ الظاهر من اقتضاء المزية والمساواة معًا. وإنما يقتضي ما رأيت أحدا الكحل أبين منه في عينه منه في عين زيد: نفي رؤية الزائد حسنه لا نفي رؤية المساواة، وإذا لم فئه يتوصل إلى ذلك المعنى إلا بالترتيب المذكور الذي الذي

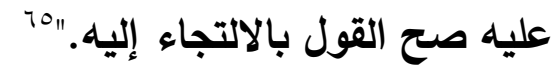
كما يلمح منه انبثاق إجراءاتهم من دافع الحاجة، التي قد تشكلت في مقاصد عدة، وأشكال متعددة، وليست مجرد إجراءات عشوائية، تم التوغل فيها حتى ولى فعاس تجاوزت حدود واقع الإشكال، وبلغت مرحلة الترف

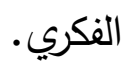

ولعل في هذا ردًا على تهمة قد تلصق بالمسألة من جانب آخر، وهي نفي وجودها في الواقع اللغوي استنادًا إلى قلة نماذجها المسموعة وطغيان مثالها المصنوع الذي أصبح لازمة لها، وتقسير محاولة

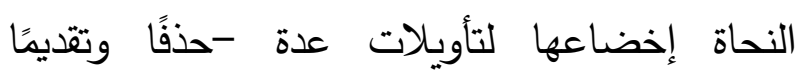
وتأخيرًا - يجعلها أقرب إلى الترف الفكري.

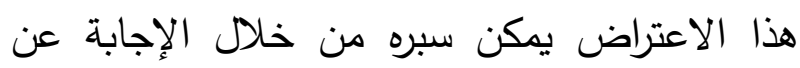

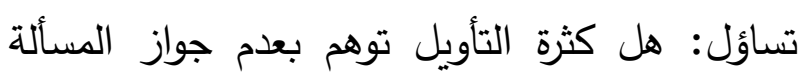

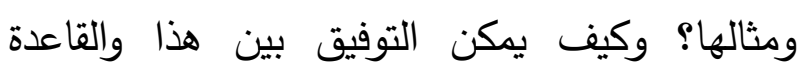

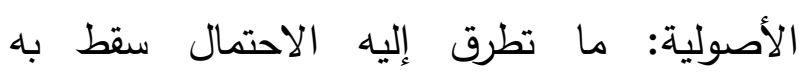
الاستدلال؟ الاصول:

ما يقبله عقل المنصف والواعي بواقع الدرس النحوي أن التأويل وكثرة إجراءاته في المسألة ليست مستندًا
أثناء إجراءات إعادة صياغة مثال المسألة حذفًا أو تقديمًا أو تأخيرًا، أو أثناء تقليب النظر في تأويلات

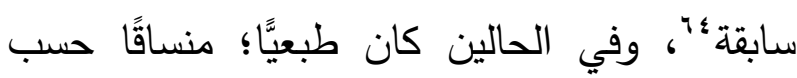
إجراءات التفكير المتواصلة لإيجاد حل فل إثكال المثال، ولم يصل حدَّ المغالاة فيه. المحور الثاني: ملامح التفكير النحوي في وصف لهف مسألة الكحل وتأويلها في الميزان. يمكن القول بأن تباين ملامح التفكير النحوي النديزان.

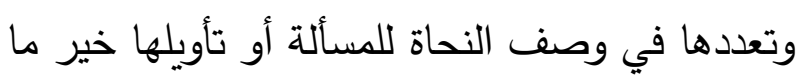
يجسد إدراكهم لمراعاة مناسبة الإجراء المتخذ لدالاهة سياق المثال عامة، ولدلالة علاقة الكلمتين محل الإثكال ببعضها خاصة.

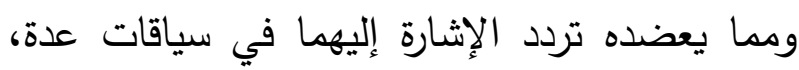

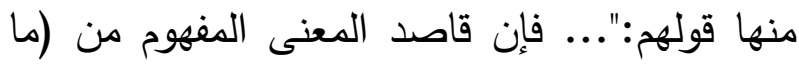
رأيت أحدا أحسن في عينه الكحل منه في عين زيد)، إمّا بأن تجعل أفعل صفة لما قبلها رافعة ما بعدها، وإما أن تجعله خبرا للكحل، وهذا الوجه ممتنع بإجماع العرب، لاستلزامه الفصل بالمبتدأ بين أفعل

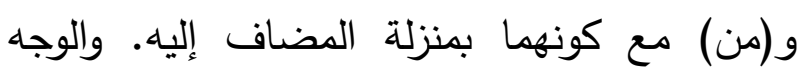
الآخر لم يجمع على منعها، بل هو جائز عند بعضهم، فلما ألجأت الحاجة إليه اتفق عليه.

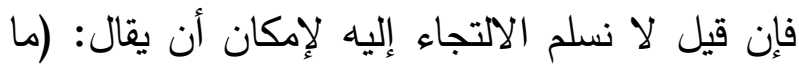
رأيت أحدا الكحل أحسن في عينه منه في عين زيد). فالجواب أن إمكان هذا اللفظ مسلّم، ولكن ليس

"ينظر على سبيل التمثيل: أبو حيان الأندلسي، التنييل و التكميل في شرح

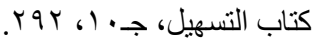

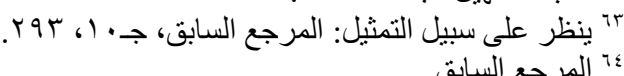


كثرة التأويلات متجاوزة حدود واقع التركيب، لكنه في سياق مسألة الكحل غير وارد؛ لأنه إجراء اضطر إليه النحاة لحاجة دعت إليه، سواء أكان في سياق وصفها أم في سياق محاولة إرجاعها إلى أصلها.

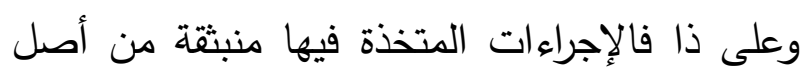
محاولة فهم الإشكال، وإعادته إلى أصله، ولم يكن اجتهادًا عقليَّا محضًا. - ل ل الخ تخو الثواهد النحوية في الدرس النحوي عمومًا، من احتمالات في مضان كثيرة ومع ذا يستل بها في مواضعها. يعضد هذا الرأي تصريح أحد النحاة بجوازها في قوله: "ولوقوع التغيير الكثير في العبارة الثالثة من الحذف والتقديم والتأخير ، ربما يتوهم أنها غير جائزة، فلذلك أحتاج إلى إيراد نظيرٍ لها جاء في كلام

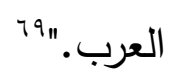

\section{النتائجج: - 2}

خلصت الدراسة إلى نتائج من أهمها: • تجسدت ملامح التفكير النحوي في مسألة الكحل مل في وصف المسألة وتأويلها والأسس المستند إليها - فيهما

- تجسدت بؤرة الإشكال في المسألة في فرعين مكملين لبعضهما: إشكال مخالفة الأصل لعمل اسم التفضيل ورفعه الظاهر، وإشكال فهم العلاقات التي تربط كلمات المثال ببعضها. • برزت ملامح التفكير النحوي في وصف مسألة 9" عبد القادر عمر البغدادي، خزانة الأدب ولب لباب لسان العرب، جـ،،
للقول بعدم جوازها؛ لأسباب عدَّة، يمكن بيانها على

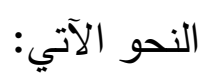
- كثرة التأويلات لم تقتصر على مثال المسألة المصنوع بل شملت ما ورد مجسدًا لها من شواهد مسموعة، ومن أكثرها دورانًا في مصنفاتهم: • حديث (ما من أيامٍ أحبَّ إلى اللهِ فيها الصومُ منه له هي عَشْرِ ذي الحجةِ) مررت على وادي السباع ولا أرى كوادي السباع حين يظلم واديا

$$
\begin{aligned}
& \text { وقول الآخر:" } \\
& \text { ما علمت امزْعًا أحَبَّ إليه الب الب }
\end{aligned}
$$

ذذل منه إلِيك يَا ابْنَ سِنان

- تعامل النحاة في الدرس النحوي مع بعض القضايا النحوية القائمة على شاهد واحد ولم ينكروا وجودها، أو ألصقوها بما هو خارج عنها فكيف بمسألة وردت فيها شواهد عدة. - قد يكون هذا الاعتراض واردًا ولاسيما إذا كانت

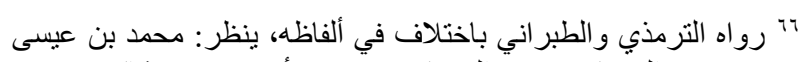

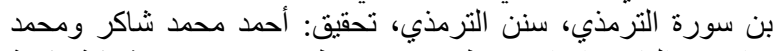

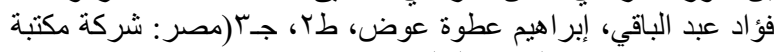

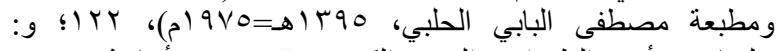

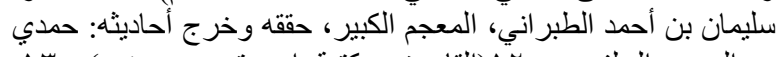

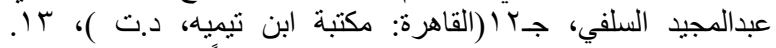
وتناقلته المصنفات النحوية بذات اللفظ، ينظر مثلاً: سيبويه، الكتاب، ج

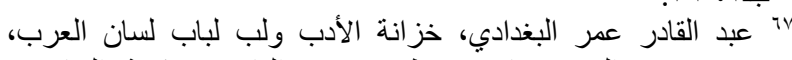

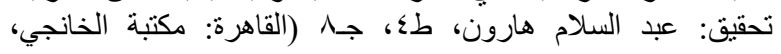

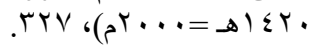
״ ينظر في: عبدالرحمن السيوطي، همع الهوامع في شرح جمع الجوامع،

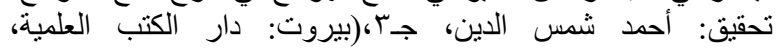

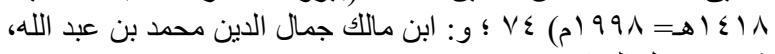

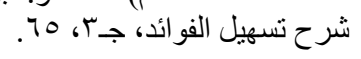


الكحل وتتنينها في سبر حقيقته وفي استدراكاتهم استحضارها في تعيين وجوه التقاطع بين التراكيب وتعقياتهم لإجراءات غيرهم وفي رصد تعاملهم مع والتباعد بينها. برز القياس في مسألة الكحل في منحيين: قياس إجراءاي التفسير والتقعيد .

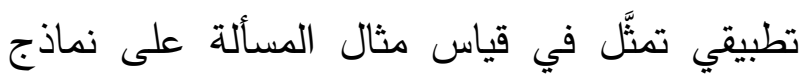

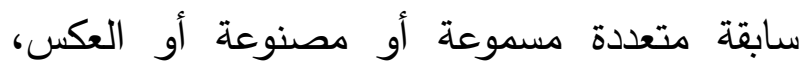
وقياس نظري تمثنّل في قياس عمل اسم التفضيل

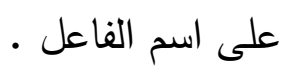
• ظهرت القواعد الكلية في المسألة في نسقها لحها النحوي المألوف تارة، ومتداخلة مع النسق الفقهي عند بعض النحاة تارة أخرى. تأتي المقارنة في سياق المسألة بنمطيها الموازنة بين المتشابهات والمختلفات، ومن بعديها الثكلي والمعنوي.

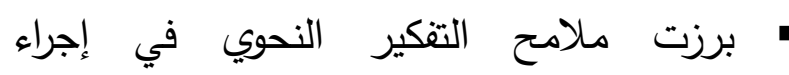
الافتراض طبعية أثناء إجراءات إعادة صياغة مثال

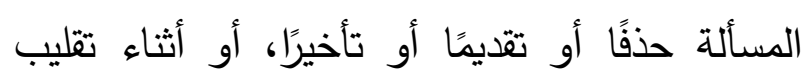
النظر في تأويلات سابقة، وتجسدت في أمثال قول

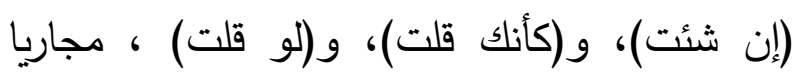

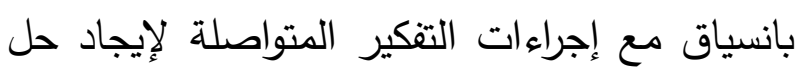
إثكال المثال، ولم يصل حدّ المغالاة فيه.

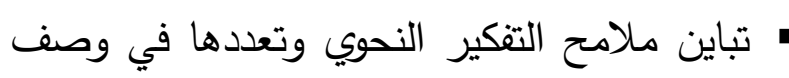

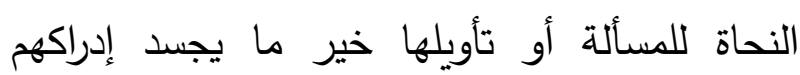
لمراعاة مناسبة الإجراء المتخذ لدلالة سياق المثال

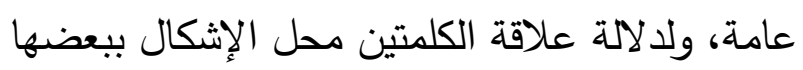
برزت ملامح التفكير النحوي في إجراء التفسير

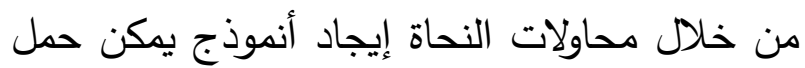
عمل اسم التفضيل عليه، وتعدد تفسيراتهم له . تؤصل الاشتراطات التي وضعها النحاة لحل إثكال مسألة الكحل ملمحًا عامًا من ملامح التفكير النحوي وهو تحقيق التكامل في صوغ أسس القواعد النحوية الخارجة عن أصلها، ومقاربتها منه، وإدراك عميق لعلاقة الكلمات ببعضها وتأثيرها في بعضها ونها قوة أو ضعفًا. " برزت ملامح التفكير النحوي في تأويل المسألة في نمطين: الفرار من تعارض الأصول، والاستتاد إلى العصف الذهني (تقليب وجهات النظر ). • برزت ملامح التفكير النحوي المستتبطة من الأسس المستند إليها في وصف المسألة وتأويلها في لمئن نمطين مكملين لبعضهما في أحايين كثيرة: ملامح تتظيرية تتعلق بالتأصيل والتقعيد، وتتمثل في القياس

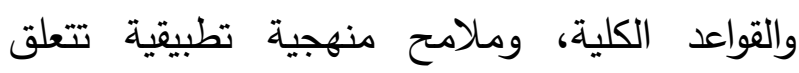

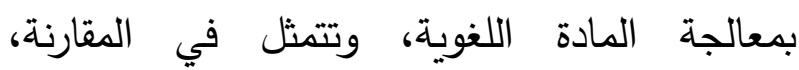
والافتراض. • تأتي الملامح التظيرية التي تتعلق بالتأصيل والتقعيد لتوسيع دائرة الحكم على الثيء لينضم إليه أفراده، ولتعاد إليه شوارده، ووسيلة منظمة يساهم 
القاهرة: مكتبة الآداب.

أبو حيان الأندلسي

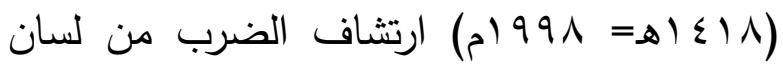

العرب، تحقيق وشرح ودراسة: رجب عثمان

محمد، مراجعة: رمضان عبد التواب، القاهرة:

مكتبة الخانجي.

(د.ت) التذييل والتكميل في شرح كتاب التسهيل،

تحقيق: حسن هنداوي، ج، دمشق: دار القلم.

الخطيب، محمد عبدالفتاح (د.ت) ضوابط الفكر

النحوي، القاهرة: دار البصائر .

ابن السراج، أبو بكر محمد بن السري (د.ت)

الأصول في النحو، تحقيق:عبدالمحسن الفتلي،

$$
\text { بيروت: مؤسسة الرسالة. }
$$

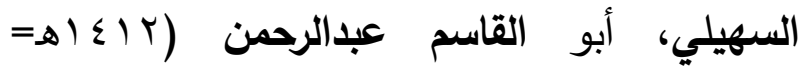
r99 (م)، نتائج الفكر في النحو (بيروت: دار

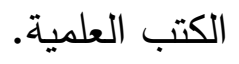

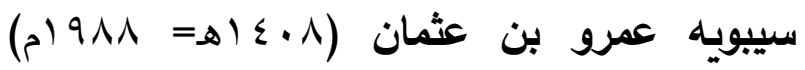
الكتاب، تحقيق: عبدالسلام هارون، طس، القاهرة:

مكتبة الخانجي.

السيوطي، عبدالرحمن بن أبي بكر

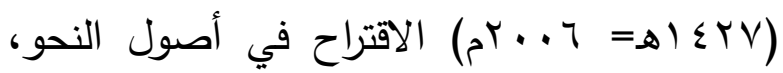

ضبط وتعليق: عبدالحكيم عطية، ط广، دمشق:

دار البيروني.

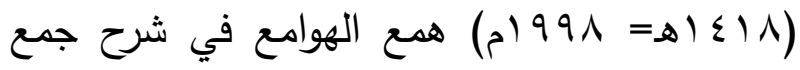

الجوامع، تحقيق: أحمد شمس الدين، بيروت: دار

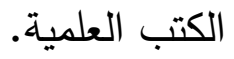

تعدد ملامح التفكير النحوي في مسألة الكحل نتيجة طبعية لدافع الحاجة التي قد تشكلت في مقاصد عدة، وأشكال متعددة، وليست مجرد إجراءات عشوائية، تم التوغل فيها حتى تجاوزت حدود واقع الإشكال، وبلغت مرحلة الترف الفكري. نفت الدراسة تهمة عدم وجود المسألة في الواقع اللغوي استنادًا إلى الأدلة التي توصلت إليه . قائمة المصادر والمراجع:

الأسترباذي، الرضي (997 (م) شرح الرضي على الكافية، تصحيح وتعليق: يوسف حسن عمر، طץ ، بنغازي: منشورات جامعة قاريوس.

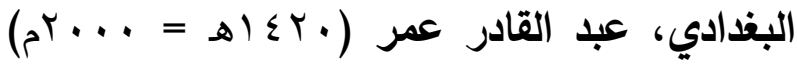
خزانة الأدب ولب لباب لسان العرب، تحقيق: عبد السلام هارون، طء، القاهرة: مكتبة الخانجي.

التادفي، محمد بن إبراهيم بن الحلبي (1995م) كحل العيون النجل في حل مسألة الكحل، تحقيق: حاتم بن صالح الضامن، منشور في

$$
\text { (المورد)، مجلد(بr)، العدد( (). }
$$

الترمذي، محمد بن عيسى بن سورة (0با (9ه = 9V0 (م) سنن الترمذي، تحقيق: أحمد محمد شاكر ومحمد فؤاد عبد الباقي، إبراهيم عطوة عوض، طب، مصر: شركة مكتبة ومطبعة مصطفى البابي الحلبي.

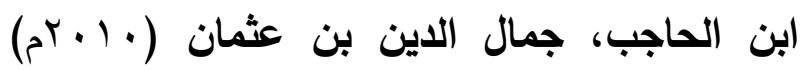
الكافية في علم النحو، تحقيق: صالح الشاعر، 


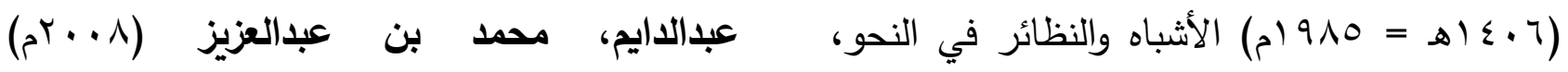
الاستدلال النحوي: نحو نظرية معاصرة لأصول تحقيق: عبدالعال سالم مكرم، بيروت: مؤسسة

$$
\text { النحو العربي، القاهرة: دار الهاني. }
$$

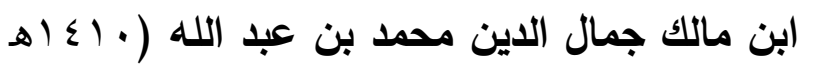

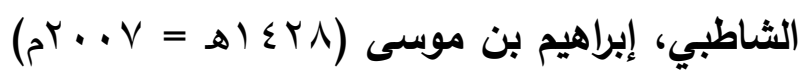

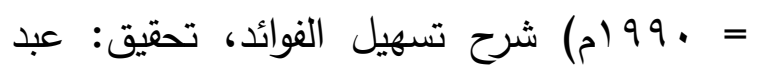
الرحمن السيد ومحمد بدوي المختون، الجيزة: هجر للطباعة والنشر - مان المقاصد الثافية في شرح الخلاصة الكافية، تحقيق: محمد إبراهيم البنا وعبد المجيد قطامش، مكة المكرمة: معهد البحوث العلمية وإحياء ابن منظور محمد بن مكرم(د.ت) لسان العرب، التراث الإسلامي بجامعة أم القرى.

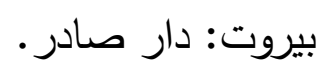

الصبان، محمد بن علي (د.ت) حاشية الصبان:

النكساري، شمس الاين محمد بن إبراهيم (9Av (ام) دادر) شرح الأشموني على ألفية ابن مالك ومعه شرح رسالة على مسألة الكحل من الكافية، تحقيق: عبدالفتاح أحمد الحموز ، المنشور في مجلة مؤتة للبحوث والدراسات، العدد الثاني، المجلد الثاني.

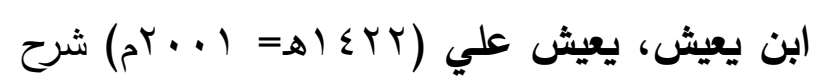

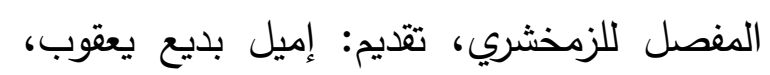

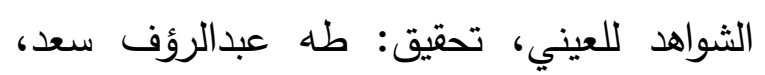
د.م: المكتبة التوفيقية.

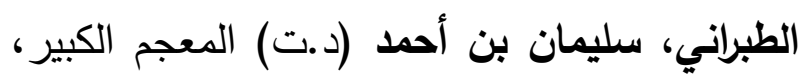

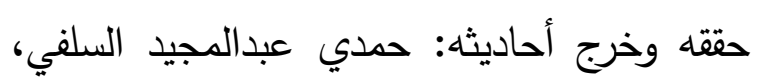
بيروت: دار الكتب العلمية. القاهرة: مكتبة ابن تيميه. طليمات، غازي مختار (1) الهـ التأويل في فهم النص، بحث منشور في مجلة كلية الدراسات الإسلامية العربية، دبي، العدد 


\title{
Features of Syntactic Analysis in Describing (kohl) question and Its Interpretation between Need and Intellectual Luxury
}

\author{
Dr. Fauzeya Badah Mokhled Al-otabi \\ Associate Professor of Linguistics, Faculty of Arts \\ Jeddah - King Abdul Aziz University
}

\begin{abstract}
Kohl" question is an example of an obstacle in the implementation of Factor Theory in a syntactic lesson. This is because it is a deviation of the scope of the rule of superlatives, despite citing hearsay evidence representing them. This is why Syntacticians devoted their attention when dealing with them. The study represents their efforts when solving the issue and ultimately attempts to answer the question: Were their way of thinking coming out of necessity or was it because they had no limits in their imagination in a way that their actions actually constituted an intellectual luxury?

I followed an analytical descriptive methodology and concluded that Syntacticians' deep awareness to the relationship between vocabulary of composition and their achievement to the meaning of the general context. This was evidently witnessed in their description of the problem, their attempts to control it, their interpretation, and the bases on which it is built. Their way of thinking appeared in two forms: theoretical aspects concerned with their activation of the idea of analogy and general principles, and the methodological aspects of their attempts to solve the linguistic material on hand which was represented in comparison and assumption. The syntacticians therefore were forced to come up with a solution to a necessity stemming from that exit and its interpretation.
\end{abstract}

Key words: Kohl question, Superlatives, Need, intellectual luxury 